The early rapid fall in haemoglobin with reticulocytopenia and a positive DAT with undetectable serum haptoglobin is interesting. This was noted at a time when normal blood neutrophil and platelet counts were maintained and is consistent with an autoimmune pathogenesis, the antibody perhaps also being active against red cell precursors. The marrow appearances supported this possibility.

In summary, a severe anaemia developed in a patient with B-CLL at a time of increasing disease activity. Evidence for immune haemolytic anaemia was detected but the picture rapidly developed into that of bone marrow aplasia. A prompt and complete response to anti-thymocyte globulin was obtained, suggesting a role for $\mathrm{T}$ lymphocytes in the pathogenesis of this unique complication of CLL.
We are grateful to Dr N Testa (Department of Experimental Haematology, Christie Hospital, Manchester) for performing bone marrow culture.

1 Chikkapa G, Zarrabi MH, Tsan MF. Pure red cell aplasia in patients with chronic lymphocytic leukaemia. Medicine patients with chror

2 Radosevich CA, Gordon LI, Weil SC, Marden RJ, Rosen ST. Complete resolution of pure red cell aplasia in a patient with chronic lymphocytic leukaemia following antithymocyte globulin therapy. $J A M A$ 1988;259:723-5.

3 Christen R, Morant R, Fehr J. Cyclosporin A therapy of pure red cell aplasia in a patient with B-cell chronic lymphocytic leukaemia. Eur J Haematol 1989;42:303-7.

4 Mangan KF, Chikkappa G, Farley PC. T gamma cells suppress growth of erythroid colony forming units in vitro in the pure red cell aplasia of B-cell chronic lymphocytic leukaemia. J Clin Invest 1982;70:1148-56.

5 Tong J, Bacigalupo A, Piaggio G, Figari O, Marmont A Effect of antilymphocyte globulin (ALG) on bone marrow $\mathrm{T} /$ non- $\mathrm{T}$ cells from aplastic anaemia patients and normal T/non- $\mathrm{T}$ cells from aplastic anaemia patien

\title{
Bleeding diathesis coincident with chronic myelomonocytic leukaemia
}

\author{
S E Heard, P Revell, L J Holland, A D F Hurdle, G F Savidge
}

Supra-Regional Haemophilia Centre, St Thomas's Hospital, Lambeth Palace Road, London SE1 7EH S E Heard $P$ Revell L J Holland

G F Savidge

Epsom District Hospital

A D F Hurdle

Correspondence to: Dr S E Heard, 49 Fair-AFar, Edinburgh EI14 6QB. Accepted for publication 9 May 1991

\begin{abstract}
Two important haematological problems were found in an otherwise healthy 78 year old man: chronic myelomonocytic leukaemia; and a complex, acquired, hyperfibrinolytic bleeding disorder characterised by prolonged coagulation times, deficiency of coagulation factors $\mathrm{V}, \mathrm{X}$, and XI, anti-thrombin III and proteins $C$ and $S$, with high concentrations of circulating tissue plasminogen activator, and low concentrations of plasminogen activator inhibitor.

There may be a causal relation between the two conditions, with the peripheral blood monocytes mediating the hyperfibrinolytic process by the abnormal production of tissue plasminogen activator, though no previous description of a similar association has been reported.
\end{abstract}

\section{Case report}

Two years before referral, the coincidental diagnosis of a myeloproliferative disorder had been made during the investigation of haematuria in a 78 year old man. Urate bladder stones secondary to hyperuricaemia were diagnosed. The spleen was palpable to $3 \mathrm{~cm}$ and the blood count showed a haemoglobin $161 \mathrm{~g} / 1$, white cell count of $83.7 \times 10^{9} / 1$, and a platelet count of $417 \times 10^{9} / 1$. A bone marrow aspirate and trephine biopsy specimen showed increased cellularity with high reticulin and myeloid activity. The karyotype was normal and the leucocyte alkaline phosphatase score was increased. There was no history of major surgery.

One month later an elective prostatic biopsy was performed, leading to excessive bleeding. The results of a coagulation screen taken at the time are shown in the table. The bleeding stopped in response to fresh frozen plasma (FFP). The biopsy specimen was histologically normal.

The following year an inguinal hernia repair resulted in prolonged bleeding persisting for four weeks, requiring transfusion of red cells and daily FFP infusions. Coagulation results obtained at the time (1987) are shown in the table. An orchidectomy became necessary after the formation of a large scrotal haematoma, the histology of which was normal.

The initial referral to this centre (1988) was prior to dental treatment. The patient was otherwise well with no spontaneous bleeding or bruising and the myeloproliferative disorder was well controlled by intermittent oral hydroxyurea. Full blood count showed a haemoglobin of $137 \mathrm{~g} / \mathrm{l}$, a white cell count of $14.7 \times 10^{9} / 1$, with neutrophils $10.3 \times 10^{9} / 1$, lymphocytes $2.4 \times 10^{9} / 1$, monocytes $1.2 \times$ $10^{9} / 1$, and eosinophils $0.8 \times 10^{9} / 1$. Coagulation investigations were performed including an 


\begin{tabular}{|c|c|c|c|c|c|c|}
\hline & Normal values with units & 1986 & 1987 & 1988 & January 1990 & April 1990 (Pre-DDAVP) \\
\hline $\begin{array}{l}\text { WCC } \\
\text { Monocytes } \\
\text { Platelets } \\
\text { INR } \\
\text { INR 50:50 } \\
\text { KCT ratio } \\
\text { KCT ratio 50:50 } \\
\text { TT ratio } \\
\text { Arvin time ratio } \\
\text { Fibrinogen } \\
\text { XDP } \\
\text { DLE Exner } \\
\text { Factor V } \\
\text { Factor XI } \\
\text { Factor X } \\
\text { Factor IXc } \\
\text { Factor VII } \\
\text { Factor XII } \\
\text { Factor II } \\
\text { Factor VIII } \\
\text { Factor XIII }\end{array}$ & $\begin{array}{c}4 \cdot 5-11 \cdot 0 \times 10^{9} / 1 \\
0 \cdot 2-1 \cdot 0 \times 10^{9} / 1 \\
150-400 \times 10^{9} / 1 \\
0 \cdot 8-1 \cdot 1 \\
0 \cdot 8-1 \cdot 1 \\
0 \cdot 8-1 \cdot 2 \\
0 \cdot 8-1 \cdot 2 \\
0 \cdot 85-1 \cdot 1 \\
0 \cdot 80-1 \cdot 20 \\
1 \cdot 5-3 \cdot 5 \mathrm{~g} / 1 \\
<250 \mathrm{ng} / 1 \\
\text { Negative } \\
50-200 \mathrm{IU} / \mathrm{dl} \\
50-200 \mathrm{IU} / \mathrm{dl} \\
50-200 \mathrm{IU} / \mathrm{dl} \\
50-200 \mathrm{IU} / \mathrm{dl} \\
50-200 \mathrm{IU} / \mathrm{dl} \\
50-200 \mathrm{IU} / \mathrm{dl} \\
50-200 \mathrm{IU} / \mathrm{dl} \\
50-200 \mathrm{IU} / \mathrm{dl} \\
\text { Screening test }\end{array}$ & 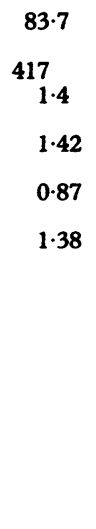 & $\begin{array}{l}324 \\
1 \cdot 7 \\
1 \cdot 48 \\
\\
2 \cdot 05 \\
40 \\
75 \\
50\end{array}$ & $\begin{array}{c}14 \cdot 7 \\
1 \cdot 18 \\
237 \\
1 \cdot 4 \\
1 \cdot 2 \\
1 \cdot 4 \\
1 \\
1 \cdot 17\end{array}$ & $\begin{array}{c}15 \cdot 7 \\
3 \cdot 77 \\
154 \\
1 \cdot 4 \\
1 \\
1 \cdot 39 \\
1.08 \\
0.92 \\
0 \cdot 87 \\
1 \cdot 45 \\
<250 \\
\text { Negative } \\
27 \\
46 \cdot 8 \\
45 \cdot 6 \\
85 \cdot 2 \\
84 \cdot 5 \\
56 \cdot 5 \\
69 \\
89 \cdot 5 \\
\text { Normal }\end{array}$ & $\begin{array}{c}38.3 \\
13.6 \\
238 \\
1.5 \\
1.3 \\
1.43 \\
1.03 \\
1.15 \\
<250 \\
\\
24.4 \\
38 \\
44 \cdot 1 \\
58 \cdot 2 \\
72.6 \\
49 \cdot 1 \\
58.4 \\
72.6\end{array}$ \\
\hline $\begin{array}{l}\text { Von Willebrand: } \\
\text { Antigen } \\
\text { Ristocetin cofactor } \\
\text { Multimers and triplets } \\
\text { Protein C } \\
\text { Anti-thrombin III } \\
\text { Protein S (free) } \\
\text { tPA } \\
\text { PAI }\end{array}$ & $\begin{array}{l}45-160 \mathrm{IU} / \mathrm{dl} \\
50-195 \mathrm{IU} / \mathrm{dl} \\
82-146 \mathrm{IU} / \mathrm{dl} \\
84-113 \mathrm{IU} / \mathrm{dl} \\
55-159 \mathrm{IU} / \mathrm{dl} \\
0.408-1.501 \mathrm{IU} / \mathrm{dl} \\
1.45-22 \cdot 61 \mathrm{AU} / \mathrm{ml}\end{array}$ & & & $\begin{array}{l}60 \cdot 2 \\
77 \\
\\
57 \cdot 6 \\
81 \cdot 4\end{array}$ & $\begin{array}{c}67 \cdot 8 \\
83 \cdot 3 \\
\text { Normal } \\
48 \cdot 1 \\
79 \cdot 2\end{array}$ & $\begin{array}{c}61 \cdot 4 \\
59 \cdot 2 \\
\text { Normal } \\
49 \cdot 7 \\
75 \cdot 8 \\
36 \cdot 7 \\
1.84 \\
0 \cdot 23\end{array}$ \\
\hline
\end{tabular}

SLE Exner (systemic lupus erythematosus Exner screening for a lupus anticoagulant) and XDPs (cross-linked fibrin degradation products); the results were as shown. To cover the dental extraction a DDAVP (desamino-d-arginine-vasopressin) infusion, FFP, and intravenous tranexamic acid were given with a course of oral tranexamic acid to follow. Extraction of a molar tooth was performed, without excessive haemorrhage.

Subsequently (1990) further investigations produced additional information. It was decided to (1) perform the investigations with the white cell count controlled by treatment and repeat when relatively uncontrolled, and (2) formally assess the effect of the administration of DDAVP. Clotting factor assays were performed using three dilutions with statistical data relating to parallelism and linearity found to be within the 5\% range. Protein C was measured by chromogenic assay and protein $S$ by enzyme linked immunosorbent assay. Concentrations of tissue plasminogen activator (tPA) and plasminogen activator inhibitor (PAI) were assessed by functional assay.

The table shows that the consistent problem was of prolonged coagulation times, low to normal fibrinogen concentrations, and deficiency of factors $\mathrm{V}, \mathrm{X}$, and $\mathrm{XI}$, antithrombin III, and proteins $C$ and $S$. There was a high concentration of TPA and a low concentration of PAI. Platelet function tests showed an inconsistent minor degree of abnormality (prolonged lag phase in response to collagen, reduced aggregation in response to adrenalin, an excessive response to arachidonic acid at $0.34 \mathrm{mM}$ ). Platelet aggregometry at the most recent assessment was difficult due to problems with obtaining platelet rich plasma in the presence of a high white cell count, but the results were similar to those obtained previously. There were no significant changes in coagulation times, factor assays (other than a rise in factor VIII and von Willebrand factor concentration), or platelet function following the administration of DDAVP. The Ivy bleeding time has been measured on several occasions (six, five, and 6.3 minutes) and is within the normal range (3.5 to 9.5 minutes) showing no variation in response to changes in the white cell count or to DDAVP.

Additional investigations failed to show additional pathology, in particular liver function tests, urea and electrolytes, autoantibody screen, direct antiglobulin test, erythrocyte sedimentation rate, hepatitis B serology, liver isotope scan and upper abdominal ultrasound scan were all normal.

The peripheral blood and bone marrow appearances were characteristic of chronic myelomonocytic leukaemia (CMML) with an increasing percentage of monocytes in the peripheral blood, a hypercellular marrow with minor degrees of trilineage dysplasia, and increased numbers of mature and immature monocytes. Serum and urinary lysozyme activities were raised and the karyotype remained normal.

\section{Comment}

This patient had an unusual, acquired disorder of coagulation with consistently low concentrations of certain coagulation factors and prolonged coagulation times. This would support a diagnosis of chronic, systemic fibrinolysis, mediated by the raised concentrations of tPA found in the most recent investigations. Whether this is an epi-phenomenon or is directly related to the CMML is difficult to ascertain; there is no previous report of any similar finding. Monocytes in culture have 
been reported to secrete a tissue type plasminogen activator ${ }^{1}$ so it may be that the abnormal clone present in this patient has switched on this ability to a greater than normal degree. Alternatively, the underlying process may be related to the procoagulant properties of monocytes with a compensatory secondary hyperfibrinolysis. The clinical presentation, however, is one of bleeding, with no evidence of thrombotic damage over several years. An association of high tPA concentrations and low concentrations of PAI has been shown in patients with liver disease, ${ }^{2}$ but investigations have not shown any liver pathology in this case. A lupus inhibitor seems unlikely given the lack of interference in factor assays, the negative Exner test, and absence of any other evidence of autoimmune disease.

Infusion of FFP seems to be the most appropriate approach in the treatment and prophylaxis of bleeding episodes in this patient. The role of tranexamic acid is debatable-the ability to moderate fibrinolysis is useful, but in these circumstances there is a theoretical risk of precipitating disseminated intravascular coagulation. The administration of DDAVP seems to have no effect.

1 Hart PH, Vitti GF, Burgess DR, Singleton DK, Hamilton JA. Human monocytes can produce tissue-type plasminogen activator. J Exp Med 1989;169:1509-14.

2 Booth NA, Anderson JA, Bennett B. Plasminogen activators in alcoholic cirrhosis: demonstration of increased tissue type and urokinase type activator. J Clin Pathol 1984; type and

\title{
Squamous cell carcinoma arising in endometriosis of the ovary
}

\author{
K N Naresh, V K Ahuja, C Rama Rao, G Mukherjee, M K Bhargava
}

\begin{abstract}
Squamous cell carcinoma arising in ovarian endometriosis is extremely rare, but a case is reported in a 62 year old woman. If such an ovarian tumour is discovered evidence of teratoma, Brenner tumour, or endometriosis should be sought. Extensive sampling is mandatory as the developing tumour often overgrows the foci of endometriosis, thus obliterating evidence of its origin.
\end{abstract}

Malignant change. occurs in foci of endometriosis of which the most common site is the ovary. The resulting tumour is often an endometrioid adenocarcinoma. Mixed müllerian tumours, clear cell adenocarcinomas, ${ }^{1}$ and endometrial stromal sarcomas have also been described. The occurrence of squamous cell carcinoma is extremely rare. ${ }^{2}$ Conversely, squamous cell carcinomas of the ovary usually arise in a pre-existing mature teratoma or a Brenner tumour. Primary squamous cell carcinoma and squamous cell carcinoma arising in ovarian endometriosis form an extremely small proportion of cases. ${ }^{3}$

\section{Case report}

A 62 year old post-menopausal woman was referred to the Institute for evaluation of a pelvic mass. Examination showed a 12-14 week old, immobile, right sided mass in the pelvis. Ultrasonography showed that the mass was $10 \times 12 \mathrm{~cm}$ with hydronephrosis on the right side. Laparotomy was performed, showing a $10 \times 10 \mathrm{~cm}$ right ovarian mass, adherent to the posterior pelvic peritoneum over the sacral promontory and pouch of Douglas and the posterior surface of the uterus. The parametrium on the right side had been infiltrated. There was no evidence of tumour elsewhere in the abdominal cavity. A total abdominal hysterectomy, left salpingooophorectomy and debulking of the right ovarian mass with partial omentectomy were carried out. Residual disease was left behind in the parametrium and pouch of Douglas.

After surgery, the patient was given multiagent chemotherapy, but she gradually deteriorated and died two months later. Necropsy was not performed.

\section{Pathology}

Gross examination of the specimen showed a right ovarian mass $10 \mathrm{~cm}$ in diameter infiltrating the posterior wall of the uterine corpus. Its outer surface was nodular and cut section was predominantly white and solid, interspersed with small cystic spaces, $0.3 \mathrm{~cm}-1.5 \mathrm{~cm}$ in dimension. Papillary areas were not identified. The cervix and left adnexae were normal. 